\title{
OCENA WPLYWU WARTOŚCI LICZB LOSOWYCH W METODZIE HYDROPROJEKTU NA PARAMETRY FALI HIPOTETYCZNEJ
}

\begin{abstract}
Metoda Hydroprojektu stosowana do wyznaczania fal hipotetycznych wykorzystuje wartości liczb losowych w zakresie od $-0,1$ do 0,2 uzyskane $\mathrm{z}$ generatora liczb losowych do uzmiennienia przebiegu czasowego wezbrania. Celem niniejszej publikacji jest sprawdzenie, w jakim zakresie ulegają zmianom parametry wezbrania takie jak: objętość i czas trwania, w wyniku stosowania generatora liczb losowych. Analizę przeprowadzono dla danych zarejestrowanych na 30 wodowskazach położonych na obszarze zlewni górnej Wisły. Wybrane posterunki reprezentują zlewnie o różnej powierzchni i różnym charakterze. Reprezentowane są zlewnie górskie, podgórskie, wyżynne i nizinne. Najmniejsza zlewnia potoku Lubieńka ma powierzchnię 46,9 $\mathrm{km}^{2}$, a największą jest zlewnia Wisły po przekrój wodowskazowy Zawichost $50732 \mathrm{~km}^{2}$. Przy wyborze tzw. hydrogramu wzorcowego dla metody Hydroprojektu, wykorzystano opracowaną przez autora publikacji ,,formułę na objętość”, która w sposób zadawalający wyznacza wartość objętości wezbrania dla zadanej powierzchni zlewni. Formuła ta może być stosowana zarówno dla dorzecza Wisły jak i Odry. Z uwagi na to, że w metodzie Hydroprojektu nie wyznacza się w sposób jednoznaczny poziomu odcięcia wezbrania, przyjęto dla celów porównawczych, że obliczenia będą prowadzone dla wartości przepływów większych

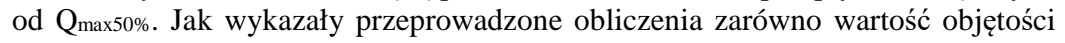
jak i czasu trwania wezbrania wykazują duże zróżnicowanie w stosunku do wezbrania przy wyłączonym generatorze liczb losowych. Odchylenie przy wartości liczby generatora $0,2 \mathrm{w}$ zakresie czasu wznoszenia i opadania w stosunku do wyłączonego generatora liczb zmienia się od $16 \%$ do $58 \%$. Podobne wartości odchylenia obliczono dla objętości wezbrania. Nie udało się ustalić przyczyn tak dużej rozpiętości wyników. Zaleca się ograniczenie górnej wartości liczby losowej do 0,1 i stosować generator w za-kresie od $-0,1$ do 0,1 .
\end{abstract}

Słowa kluczowe: metoda Hydroprojektu, fala hipotetyczna, formuła na objętość, metoda krakowska, parametry wezbrania, wezbranie

\footnotetext{
${ }^{1}$ Wiesław Gądek, Politechnika Krakowska, ul. Warszawska 24, 30-155 Kraków, tel. 1262828 54, wieslaw.gadek@iigw.pk.edu.pl
} 


\section{Wstęp}

Opracowana przez Hydroprojekt w 1989 roku metoda wyznaczania wezbrań teoretycznych (potocznie nazywanymi falami hipotetycznymi) należy do jednych z ciekawszych propozycji w tym zakresie. Jej unikatowość w stosunku do innych metod polega na zmianie przebiegu wezbrania w czasie przy zachowaniu maksymalnej wartości przepływu w hydrogramie [13]. Uzyskuje się to poprzez zastosowanie generatora liczb losowych w zakresie od $-0,1$ do 0,2 , wydłużając lub skracając czasy wznoszenia i opadania fali. W stosowanych podobnych rozwiązaniach, zmianom podlega nie tylko czas przebiegu wezbrania, ale i wartości przepływu [22].

Wezbrania hipotetyczne znalazły szerokie zastosowane w gospodarce wodnej, różnią się one od przepływów miarodajnych i kontrolnych tym, że posiadają dodatkową informację o przebiegu wezbrania, objętości, czasie wznoszenia oraz czasie trwania wezbrania. Dzięki tej nowej jakości danych można wykonywać obliczenia transformacji fali $\mathrm{w}$ korycie cieku lub poprzez zbiornik retencyjny [21]. Liczba możliwych zastosowań tych fal systematycznie rośnie. Na chwilę obecną znajdują one zastosowanie w szeroko rozumianym ryzyku powodziowym $[1 ; 23 ; 24]$, gdzie oceniane jest przestrzenne ryzyko, w którym stara się określić straty mienia i o ile jest to możliwe ustalić stan zagrożenia dla życia ludzkiego [3;14]. Podejmowane są próby ustalenia wpływu kanalizacji deszczowej na odpływ ze zlewni zurbanizowanej a także w zagadnieniach związanych $\mathrm{z}$ jakością wody. Brak jest podobnych rozwiązań $\mathrm{w}$ zakresie niźówek i suszy a ich negatywne skutki oddziaływania są podobne i dotyczą znacznie dłuższych czasów trwania [20].

Metod dotyczących wyznaczania wezbrań hipotetycznych w zlewniach kontrolowanych jest stosunkowo dużo w naszym kraju, brak jest ich dla zlewni niekontrolowanych. Dla zlewni niekontrolowanych podejmowane są próby wykorzystania modeli hydrologicznych do wyznaczania hydrogramów [8; 17; 25]. W rozwiązaniach tych zakłada się, że prawdopodobieństwo maksymalnego opadu jest takie samo jak prawdopodobieństwo odpływu ze zlewni. Brak w nich jest zasad wyznaczanie przebiegu w czasie opadu o zadanym prawdopodobieństwie przewyższenia $[2 ; 19 ; 26]$. Trudno też jest jednoznacznie podać, dla jakiej maksymalnej powierzchni zlewni można tego typu rozwiązania stosować. Być może rozwiązaniem jest zastosowanie integralnych modeli hydrologicznych o parametrach rozłożonych takich jak model WISTOO $[4 ; 5 ; 16]$ w który przeznaczony jest dla zlewni od 10 do $1000 \mathrm{~km}^{2}$ lub stosowanie modeli o parametrach częściowo rozłożonych, w których modele hydrologiczne typu opadodpływ były by wspomagane modelem hydrodynamicznym. W tych modelach nie ma ograniczeń powierzchni zlewni. Można też wykorzystać „formułę na objętość", która umożliwia ustalenie wartości objętości wezbrania hipotetycznego dla zlewni do $1000 \mathrm{~km}^{2}$ a przebieg wezbrania wyznaczany jest na podstawie hydrogramu jednostkowego UHI SCS [10; 11]. 
W zlewniach kontrolowanych do wyznaczania fal hipotetycznych stosowane są metody:

- Reitza i Krepsa [12],

- dwie metody Strupczewskiego [18],

- McEnroe [15],

- Hydropojektu [13],

- Politechniki Warszawskiej [7],

- krakowska [6,7].

Niezależnie od przyjętej metody użyte dane do wyznaczania hydrogramów teoretycznych powinny być zarejestrowane w systemie wodowskazowym lub telemetrycznym. Dane z systemu limnigraficznego nie powinny być stosowane z uwagi na uśredniony przepływ, który zniekształca przebieg w czasie przepływy teoretyczne [9].

Celem niniejszej publikacji jest dokonanie oceny jak skrajne wartości w stosowanym generatorze liczb losowych w metodzie Hydroprojektu wpływające na zmianę czasu wznoszenia i opadania wezbrania przekładają się na zmiany objętości obliczanego wezbrania. Tą ocenę przeprowadzono dla 30 przekroi wodowskazowych usytuowanych na obszarze górnej Wisły.

\section{Metodyka badań}

\subsection{Krótki opis metody Hydroprojektu}

Metoda Hydroprojektu wyznaczania fal hipotetycznych została opracowana w 1989 roku [13]. Metoda ta zakłada, że hydrogramy są maksymalne dopasowanie do rzeczywistych zarejestrowanych wezbrań. Założenie to realizowane jest poprzez wyznaczanie fali ze zbioru historyczne zarejestrowanych wezbrań o podobnym charakterze i tej samej genetyce powstania np. wezbrania opadowe lub roztopowe. Przy ich konstrukcji wykorzystuje się losowo wygenerowany czas trwania przebiegu fali w strefie wznoszenie i w strefie opadania. Przy wyborze fali wzorcowej ze zbioru fal historycznie zarejestrowanych stosowane jest jedno z trzech kryteriów:

- najwyższego przepływu dla zarejestrowanych wezbrań,

- maksymalnie zbliżonej wartości przepływu w kulminacji do maksymalnego zadanego przepływu dla fali hipotetycznej,

- typowego kształtu wezbrania rzeczywistego.

Przebieg części wznoszącej hydrogramu i części opadającej jest wyznaczany w sposób niezależny z wykorzystaniem generatora liczb losowych z przedziału od -0,1 do 0,2, który umożliwia modyfikację czasową przebiegu fali hipotetycznej stosunku do rzeczywistego przebiegu (rys.1).

Dla części wznoszącej współrzędne czasowe obliczane są z zależności: 


$$
t_{w_{i}}^{h}=t_{w_{i}}\left(1+G_{w} \frac{Q_{\operatorname{maxp} \%}}{Q_{\max }}\right)
$$

gdzie: $t_{w_{i}}^{h}$ - współrzędne czasowe fali hipotetycznej dla części wznoszącej [h],

$t_{w_{i}}$ - współrzędne czasowe dla części wznoszącej wezbrania rzeczywistego $[\mathrm{h}]$,

$\mathrm{G}_{\mathrm{w}}$ - liczba losowa z przedziału $[-0,1 ; 0,2]$ ustalana na podstawie niezależnych losowań dla części wznoszącej wezbrania hipotetycznego $[-]$,

$Q_{\operatorname{maxp} \%}$ - przepływ maksymalny o zadanym prawdopodobieństwie przewyższenia dla fali hipotetycznej $\left[\mathrm{m}^{3} \mathrm{~s}^{-1}\right]$,

$Q_{\max }$ - przepływ maksymalny dla fali rzeczywistej $\left[\mathrm{m}^{3} \mathrm{~s}^{-1}\right]$,

$i$ - $\quad$ kolejne współrzędne czasowe.

Wartości przepływu dla części wznoszącej wyznacza formuła

$$
Q_{w_{i}}^{h}=Q_{0}^{w}+\frac{Q_{\operatorname{maxp} \%}-Q_{0}^{w}}{Q_{\max }-Q_{0}^{w}}\left(Q_{w_{i}}-Q_{0}^{w}\right)
$$

gdzie: $Q_{w_{i}}^{h}$ - wartości przepływu dla fali hipotetycznej wyznaczonych współrzędnymi czasowymi $t_{w_{i}}^{h}\left[\mathrm{~m}^{3} \mathrm{~s}^{-1}\right]$

$Q_{0}^{w}$ - wartości przepływu początkowego dla części wznoszącej wezbrania rzeczywistego $\left[\mathrm{m}^{3} \mathrm{~s}^{-1}\right]$,

$Q_{w_{i}}$ - wartości przepływu w części wznoszącej dla wezbrania rzeczywistego $\left[\mathrm{m}^{3} \mathrm{~s}^{-1}\right]$.

Dla części opadającej w podobny sposób wyznaczane są współrzędne czasowe i przepływu:

$$
t_{o_{i}}^{h}=t_{o_{i}}\left(1+G_{o} \frac{Q_{\operatorname{maxp} \%}}{Q_{\max }}\right)
$$

gdzie: $t_{o_{i}}^{h}$ - współrzędne czasowe fali hipotetycznej dla części opadającej [h],

$t_{o_{i}}$ - współrzędne czasowe dla części opadającej wezbrania rzeczywistego [h],

$\mathrm{G}_{\mathrm{o}}$ - liczba losowa z przedziału $[-0,1 ; 0,2]$ ustalana na podstawie niezależnych losowań dla części opadającej wezbrania hipotetycznego [-]. 




Rys. 1. Graniczne przebiegi wezbrań teoretycznych w metodzie Hydroprojektu dla wartości generatora w części wznoszącej i opadającej $\mathrm{G1}=0,2, \mathrm{G} 2=-0,1$ i G0 = 0. 0. Źródło: obliczenia własne

Fig. 1. Critical routes of the design floods in Hydroprojekt method for the generator values in the rising part and declining part G1=0,2, G2=-0,1 and G0 $=0$. Source: own calculations

Wartości przepływu dla części opadającej wyznacza się

$$
Q_{o_{i}}^{h}=Q_{0}^{o}+\frac{Q_{\operatorname{maxp} \%}-Q_{0}^{o}}{Q_{\max }-Q_{0}^{o}}\left(Q_{0_{i}}-Q_{0}^{o}\right)
$$

gdzie: $Q_{o_{i}}^{h}$ - wartości przepływu dla fali hipotetycznej wyznaczonych współrzędnymi czasowymi $t_{o_{i}}^{h}$ dla części opadającej $\left[\mathrm{m}^{3} \mathrm{~s}^{-1}\right]$,

$Q_{0}^{o}$ - wartości przepływu końcowego dla części opadającej wezbrania rzeczywistego $\left[\mathrm{m}^{3} \mathrm{~s}^{-1}\right]$,

$Q_{0_{i}}$ - wartości przepływu w części opadającej dla wezbrania rzeczywistego $\left[\mathrm{m}^{3} \mathrm{~s}^{-1}\right]$.

\subsection{Krótka charakterystyka wybranych zlewni}

Analizę wpływu wartości generatora liczb losowych na objętość wezbrania i czas bazowy fali w metodzie Hydroprojektu przeprowadzono dla 30 przekroi wodowskazowych, których zlewnie położone są na obszarze górnej Wisły. Wybrane zlewnie reprezentują tereny o różnych powierzchniach i topografiach, są to zlewnie o charakterze górskim, podgórskim, wyżynne oraz nizinne. Zestawienie wytypowanych do analizy zlewni przestawiono w tabeli 1, w której oprócz wartości powierzchni, podano współczynnik charakteryzujący charakter rzek pod względem dynamiki zmian przepływu IQ $\mathrm{Q}_{\mathrm{p}}$ (iloraz przepływów o zadanym prawdopodobieństwie przewyższenia). 
Tabela 1. Powierzchnie zlewni oraz iloraz IQp\% dla wytypowanych zlewni do przeprowadzanej oceny wpływu generatora liczb losowych na objętość wezbrania hipotetycznego w metodzie Hydroprojektu. Źródło: obliczenia własne.

Table 1. Catchment surface area and the quotient $\mathrm{IQ}_{\mathrm{p}} \%$ for the selected catchments for conducting the assessment of the influence of the random number generator on the design flood volume in Hydroprojekt method. Source: own study

\begin{tabular}{|c|c|c|c|}
\hline Lp. & Rzeka - wodowskaz & $\begin{array}{c}\text { Powierzchnia } \\
{\left[\mathrm{km}^{2}\right]}\end{array}$ & $\begin{array}{c}\mathrm{IQ} \mathbf{Q}_{\mathbf{p}} \% \\
{[\%]}\end{array}$ \\
\hline 1 & Lubieńka - Lubień & 46,9 & 5,6 \\
\hline 2 & Żylica - Łodygowice & 48,0 & 6.2 \\
\hline 3 & Bystra - Kamesznica & 48,2 & 5,0 \\
\hline 4 & Grajcarek - Szczawnica & 73,6 & 6,4 \\
\hline 5 & Wisłok - Puławy Dolne & 131 & 5,6 \\
\hline 6 & Wieprzówka-Rudze & 154 & 3,8 \\
\hline 7 & Jasiołka - Jasło & 164 & 3,6 \\
\hline 8 & Uszwica-Borzęcin & 265 & 5,3 \\
\hline 9 & Wisła - Skoczów & 297 & 6,3 \\
\hline 10 & Osława - Szczawne & 302 & 3,2 \\
\hline 11 & Raba - Kasinka & 353 & 5,9 \\
\hline 12 & Skawa - Sucha Beskidzka & 468 & 4,6 \\
\hline 13 & Koprzywianka - Koprzywnica & 498 & 3,4 \\
\hline 14 & Czarna - Staszów & 571 & 4,7 \\
\hline 15 & Raba - Stróża & 644 & 5,0 \\
\hline 16 & Dunajec - Nowy Targ-Kowaniec & 681 & 4,7 \\
\hline 17 & Czarna Nida - Morawica & 755 & 4,7 \\
\hline 18 & Skawa - Wadowice & 835 & 4,3 \\
\hline 19 & Biała-Koszyce Wielkie & 957 & 6,3 \\
\hline 20 & Raba - Proszówki & 1470 & 4,9 \\
\hline 21 & Przemsza - Jeleń & 2006 & 2,1 \\
\hline 22 & Poprad - Stary Sącz & 2071 & 4,1 \\
\hline 23 & Nida - Brzegi & 3359 & 4,5 \\
\hline 24 & San - Przemyśl & 3686 & 3,4 \\
\hline 25 & Wisłoka - Mielec & 3893 & 3,1 \\
\hline 26 & Dunajec - Nowy Sącz & 4341 & 5,8 \\
\hline 27 & Dunajec - Żabno - & 6735 & 5,19 \\
\hline 28 & San - Radomyśl & 16824 & 2,8 \\
\hline 29 & Wisła - Sandomierz & 31847 & 4,0 \\
\hline 30 & Wisła - Zawichost & 50732 & 3,4 \\
\hline
\end{tabular}

Iloraz $\mathrm{IQ}_{\mathrm{p} \%}$ obliczono:

$$
\mathrm{IQ}_{\mathrm{p} \%}=\frac{\mathrm{Q}_{\max 1 \%}}{\mathrm{Q}_{\max 50 \%}}
$$

gdzie: $\mathrm{IQ}_{\mathrm{p} \%}$ - iloraz maksymalnych przepływów rocznych o zadanym prawdopodobieństwie przewyższenia, [-];

$\mathrm{Q}_{\max 1 \%}, \mathrm{Q}_{\max 50 \%}$ - maksymalny przepływ roczny o zadanym prawdopodobieństwie przewyższenia $\mathrm{p}=1 \%$ i $50 \%,\left[\mathrm{~m}^{3} \cdot \mathrm{s}^{-1}\right]$. 


\subsection{Przyjęte założenia}

W metodzie Hydroprojektu podstawowym założeniem jest maksymalne dopasowanie przebiegu wezbrania hipotetycznego do hydrogramu rzeczywistego. Przebieg wezbrania jest $\mathrm{w}$ zakresie wznoszenia i opadania modyfikowany poprzez zastosowanie generatora liczb losowych z przedziału od $-0,1$ do 0,2 . Zakres ten równocześnie wyznacza obszar możliwych przebiegów fal teoretycznych (rys.1). Zasadne jest zatem uzyskanie odpowiedzi jak wpływa proponowany zakres zmienności czasowej przebiegu fali w części wznoszącej i w części opadającej na objętość wezbrania oraz na czas bazowy. Przyjęto następujące założenie, że zmienność tych parametrów będzie oceniana względem wezbrania, które zostało wyznaczone przy liczbie losowej 0. Ponieważ problem dotyczy wezbrań hipotetycznych przy ekstremalnych wartościach liczby losowej, czyli $\mathrm{G}=-0,1$ i $\mathrm{G}=0,2$, oceniane wezbrania teoretyczne wyznaczone zostały dla 4 wariantów obliczeniowych:

1. dla części wznoszącej wezbrania i opadającej wartość liczby losowej $\mathrm{G}=\mathrm{G}_{\mathrm{w}}=\mathrm{G}_{\mathrm{o}}=-0,1$;

2. dla części wznoszącej wezbrania i opadającej wartość liczby losowej $\mathrm{G}=\mathrm{G}_{\mathrm{w}}=\mathrm{G}_{\mathrm{o}}=0,2$;

3. dla części wznoszącej wezbrania liczba losowa $\mathrm{G}_{\mathrm{w}}=0,2$ a dla części opadającej wartość liczby losowej $\mathrm{G}_{\mathrm{o}}=-0,1$;

4. dla części wznoszącej wezbrania liczba losowa $\mathrm{G}_{\mathrm{w}}=-0,1$ a dla części opadającej wartość liczby losowej $\mathrm{G}_{\mathrm{o}}=0,2$;

W metodzie Hydroprojektu nie ma zdefiniowanego przepływu bazowego, który wyznacza zakres czasowy wezbrania. Wartości przepływu, od którego rozpoczyna się i kończy wezbranie różnią się w niekontrolowanym zakresie. Z tego powodu przyjęto założenie, że poziomem odniesienia do prowadzonych ocen będzie wyznaczony przez wartość przepływu o prawdopodobieństwie przewyższenia $\mathrm{Q}_{50 \%}$. Założenie to zapewnia porównywalność wyników.

Wybór hydrogramu wzorcowego z pośród czterech wcześniej wytypowanych przeprowadzono na podstawie zgodności obliczonych objętości wezbrań przy wyłączonym generatorze (liczba losowa $\mathrm{G}=0,0$ ) z „formułą na objętość" [10]. Kryterium wyboru - minimum różnic objętości. „Formuła na objętość” może być stosowana dla zlewni do $1000 \mathrm{~km}^{2}$, dla większych zlewni w celu utrzymania porównywalności wyników przyjęto zasadę najbliższej wartości objętości hydrogramu wzorcowego z ,formułą na objętość”. Dodatkowo kontrolnie korzystano z obliczonych wartości objętości z metody krakowskiej [6]. Dla wybranych przekroi wodowskazowych nie zaistniała konieczność skorzystania z takiego wyboru. Przyjęcie odpowiedniego wezbrania jest w tej metodzie podstawowym zadaniem, które decyduje o parametrach i przebiegu wezbrania hipotetycznego. Jak wykazano we wcześniejszych publikacjach, proponowane kryteria w metodzie Hydroprojektu wyboru wezbrania jako wzorcowego nie sprawdzają się [11; 13]. „Formuła na objętość" umożliwia wskazanie odpowiedniego wezbrania. 


\section{Wyniki badań}

Wyniki obliczeń dla poszczególnych wodowskazów uszeregowano według wielkości powierzchni zlewni - od najmniejszej do największej. Wartości objętości zredukowanej fal hipotetycznych (objętość powyżej poziomu odniesienia $\mathrm{Q}_{\max 50 \%}$ ) obliczono dla przyjętego przepływu maksymalnego w kulminacji fali

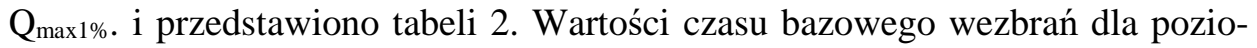
mu odniesienia $\mathrm{Q}_{\max 50 \%}$ zamieszczono w tabeli 3.

Na rysunku 2 zostały zamieszczone odchylenia względne obliczone dla objętości maksymalnej fali hipotetycznej $B_{\mathrm{v}}$ przy liczbie losowej 0,2 dla części wznoszącej i dla części opadającej. Na rysunku 3 przedstawiono odchylenie względne maksymalne dla czasu trwania $\mathrm{B}_{\mathrm{t}}$. Wartość odchylenia dla objętości obliczono:

$$
\mathrm{B}_{\mathrm{v}}=\frac{\mathrm{V}_{0,2}-\mathrm{v}_{0}}{\mathrm{~V}_{0}} 100 \%
$$

gdzie: $\mathrm{V}_{0,2}$ - objętość zredukowana (objętość powyżej poziomu odniesienia $\mathrm{Q}_{\max 50 \%}$ ) obliczona dla wezbrania przy wartości liczby losowej generatora $\mathrm{G}=0,2\left[10^{6} \mathrm{~m}^{3}\right]$,

$\mathrm{V}_{0}$ - objętość zredukowana (objętość powyżej poziomu odniesienia $\mathrm{Q}_{\max 50 \%}$ ) obliczona dla wezbrania przy wartości liczby losowej generatora $\mathrm{G}=0,0\left[10^{6} \mathrm{~m}^{3}\right]$.

Na podobnych zasadach obliczono odchylenie dla czasu bazowego fali $\mathrm{B}_{\mathrm{t}}$ :

$$
\mathrm{B}_{\mathrm{t}}=\frac{\mathrm{t}_{0,2}-\mathrm{t}_{0}}{\mathrm{t}_{0}} 100 \%
$$

gdzie: $\mathrm{t}_{0,2}$ - czas bazowy fali hipotetycznej liczony na poziomie odniesienia $\mathrm{Q}_{\max 50 \%}$ dla wezbrania przy wartości liczby losowej generatora $\mathrm{G}=0,2[\mathrm{~h}]$,

$\mathrm{t}_{0}$ - czas bazowy fali hipotetycznej liczony na poziomie odniesienia $\mathrm{Q}_{\max 50 \%}$ dla wezbrania przy wartości liczby losowej generatora $\mathrm{G}=0,0[\mathrm{~h}]$. 
Tabela 2. Objętość fal hipotetycznych w metodzie Hydroprojektu przy wartościach: liczby losowej 0,0 dla całej fali, dla liczb losowych $-0,1$ dla części wznoszącej i dla opadającej wzbrania, dla liczb losowych 0,2 dla części wznoszącej i dla opadającej, dla liczb losowych -0,1 dla części wznoszącej a dla opadającej 0,2, dla liczb losowych 0,2 dla części wznoszącej i dla opadającej -0,1. Źródło: obliczenia własne

Table 2. The volume of the design floods in Hydroprojekt method at the following values: the random number 0,0 for the whole wave, for the random numbers $-0,1$ for the rising part and declining part of the flood, for the random numbers 0,2 for the rising part and declining part, for the random numbers $-0,1$ for the rising part, and for the declining part 0,2 , for the random numbers 0,2 for the rising part and declining part $-0,1$. Source: own study

\begin{tabular}{|c|c|c|c|c|c|c|}
\hline \multirow[t]{2}{*}{ Lp } & \multirow[t]{2}{*}{ Rzeka - wodowskaz } & \multicolumn{5}{|c|}{$\begin{array}{c}\text { Objętość zredukowana wezbrania }\left[10^{6} \mathrm{~m}^{3}\right] \text { przy } \\
\text { zastosowanych wartościach liczb losowych } \\
\text { [wznosząca; opadająca] }\end{array}$} \\
\hline & & {$[0,0 ; 0,0]$} & {$[-0,1 ;-0,1]$} & {$[0,2 ; 0,2]$} & {$[-0,1 ; 0,2]$} & {$[0,2 ;-0,1]$} \\
\hline 1 & Lubieńka - Lubień & 4.55 & 3.55 & 6.54 & 4.58 & 5.51 \\
\hline 2 & Żylica-Łodygowice & 5,18 & 3,92 & 7,68 & 6,03 & 5,57 \\
\hline 3 & Bystra - Kamesznica & 3.48 & 3.02 & 4.38 & 3.69 & 3.71 \\
\hline 4 & Grajcarek - Szczawnica & 3,37 & 2,86 & 4,39 & 3,27 & 3,98 \\
\hline 5 & Wisłok - Puławy Dolne & 13,65 & 10,00 & 20,96 & 16,12 & 14,83 \\
\hline 6 & Wieprzówka-Rudze & 8,49 & 7,26 & 10,95 & 9,43 & 8,78 \\
\hline 7 & Jasiołka - Jasło & 19,66 & 16,79 & 25,41 & 19,91 & 22,28 \\
\hline 8 & Uszwica-Borzęcin & 30,20 & 25,28 & 40,03 & 34,04 & 31,27 \\
\hline 9 & Wisła - Skoczów & 26,59 & 23,44 & 32,89 & 29,08 & 27,25 \\
\hline 10 & Osława - Szczawne & 12,43 & 11,03 & 15,21 & 13,09 & 13,16 \\
\hline 11 & Raba - Kasinka & 25,51 & 21,29 & 33,97 & 26,41 & 28,85 \\
\hline 12 & Skawa - Sucha Beskidzka & 31,00 & 28,51 & 35,96 & 30,90 & 33,57 \\
\hline 13 & Koprzywianka - Koprzywnica & 4,12 & 3,66 & 5,04 & 4,48 & 4,21 \\
\hline 14 & Czarna - Staszów & 15,03 & 12,37 & 20,35 & 18,88 & 13,84 \\
\hline 15 & Raba - Stróża & 42,25 & 35,11 & 56,53 & 47,35 & 44,30 \\
\hline 16 & Dunajec - Nowy Targ - Kowaniec & 32,55 & 29,38 & 38,87 & 35,00 & 33,25 \\
\hline 17 & Czarna Nida - Morawica & 23,36 & 20,90 & 28,30 & 26,34 & 22,85 \\
\hline 18 & Skawa - Wadowice & 55,81 & 47,60 & 72,25 & 59,29 & 60,55 \\
\hline 19 & Biała-Koszyce Wielkie & 73,73 & 56,23 & 108,73 & 75,95 & 89,00 \\
\hline 20 & Raba - Proszówki & 108,2 & 76,67 & 171,1 & 112,5 & 135,3 \\
\hline 21 & Przemsza - Jeleń & 11,54 & 10,05 & 14,52 & 12,18 & 12,39 \\
\hline 22 & Poprad - Stary Sącz & 63,38 & 47,90 & 94,34 & 73,68 & 68,57 \\
\hline 23 & Nida - Brzegi & 47,29 & 37,86 & 66,16 & 56,71 & 47,31 \\
\hline 24 & San - Przemyśl & 135,9 & 121,8 & 164,0 & 140,1 & 145,7 \\
\hline 25 & Wisłoka - Mielec & 106,1 & 91,3 & 135,7 & 117,5 & 111,9 \\
\hline 26 & Dunajec - Nowy Sącz & 298,1 & 238,3 & 417,7 & 343,7 & 312,3 \\
\hline 27 & Dunajec - Żabno & 545,3 & 465,3 & 705,4 & 574,4 & 596,3 \\
\hline 28 & San - Radomyśl & 242,9 & 202,3 & 324,3 & 236,4 & 290,1 \\
\hline 29 & Wisła - Sandomierz & 944,6 & 718,8 & 1396,0 & 1139,0 & 976,4 \\
\hline 30 & Wisła - Zawichost & 1026,0 & 816,4 & 1445,0 & 1287,0 & 974,8 \\
\hline
\end{tabular}


Tabela 3. Czas trwania fal hipotetycznych w metodzie Hydroprojektu przy wartościach liczby losowej: 0,0 dla całej fali, dla liczb losowych -0,1 dla części wznoszącej i dla opadającej wzbrania, dla liczb losowych 0,2 dla części wznoszącej i dla opadającej, dla liczb losowych -0,1 dla części wznoszącej a dla opadającej 0,2 , dla liczb losowych 0,2 dla części wznoszącej i dla opadającej -0,1. Źródło: obliczenia własne

Table 3. Duration time of the design waves in Hydroprojekt method at the following values: the random number 0,0 for the whole wave, for the random numbers $-0,1$ for the rising part and declining part of the flood, for the random numbers 0,2 for the rising part and declining part, for the random numbers $-0,1$ for the rising part and for the declining part 0,2 , for the random numbers 0,2 for the rising part and declining part $-0,1$. Source: own study

\begin{tabular}{|c|l|c|c|c|c|c|}
\hline \multirow{2}{*}{ Lp } & \multirow{2}{*}{ Rzeka - wodowskaz } & \multicolumn{5}{|c|}{$\begin{array}{c}\text { Czas trwania fali hipotetycznej [h] przy zastoso- } \\
\text { wanych wartościach liczb losowych } \\
\text { [wznosząca; opadajaca] }\end{array}$} \\
\cline { 3 - 7 } & & \multicolumn{3}{|c|}{$[0,2 ; 0,2]$} & {$[-0,1 ; 0,2]$} & {$[0,2 ;-0,1]$} \\
\hline 1 & Lubieńka - Lubień & 64 & 50 & 92 & 65 & 77 \\
\hline 2 & Żylica - Łodygowice & 56 & 42 & 83 & 68 & 58 \\
\hline 3 & Bystra - Kamesznica & 61 & 53 & 77 & 67 & 63 \\
\hline 4 & Grajcarek - Szczawnica & 57 & 48 & 74 & 57 & 66 \\
\hline 5 & Wisłok - Puławy Dolne & 37 & 27 & 57 & 42 & 42 \\
\hline 6 & Wieprzówka -Rudze & 47 & 40 & 61 & 51 & 50 \\
\hline 7 & Jasiołka - Jasło & 43 & 37 & 56 & 44 & 48 \\
\hline 8 & Uszwica - Borzęcin & 43 & 36 & 57 & 48 & 45 \\
\hline 9 & Wisła - Skoczów & 40 & 35 & 49 & 46 & 39 \\
\hline 10 & Osława - Szczawne & 38 & 34 & 47 & 39 & 41 \\
\hline 11 & Raba - Kasinka & 51 & 43 & 68 & 54 & 56 \\
\hline 12 & Skawa - Sucha Beskidzka & 72 & 66 & 84 & 71 & 78 \\
\hline 13 & Koprzywianka - Koprzywnica & 40 & 36 & 49 & 42 & 43 \\
\hline 14 & Czarna - Staszów & 78 & 64 & 106 & 101 & 69 \\
\hline 15 & Raba - Stróża & 54 & 45 & 72 & 62 & 56 \\
\hline 16 & Dunajec - Nowy Targ - Kowaniec & 39 & 35 & 47 & 43 & 38 \\
\hline 17 & Czarna Nida - Morawica & 112 & 100 & 136 & 128 & 107 \\
\hline 18 & Skawa - Wadowice & 41 & 35 & 53 & 45 & 43 \\
\hline 19 & Biała - Koszyce Wielkie & 69 & 53 & 102 & 65 & 89 \\
\hline 20 & Raba - Proszówki & 45 & 32 & 71 & 47 & 56 \\
\hline 21 & Przemsza - Jeleńy & 108 & 94 & 136 & 119 & 111 \\
\hline 22 & Poprad - Stary Sącz & 55 & 42 & 82 & 67 & 56 \\
\hline 23 & Nida - Brzegi & 106 & 85 & 148 & 132 & 101 \\
\hline 24 & San - Przemýll & 61 & 55 & 74 & 63 & 65 \\
\hline 25 & Wisłoka - Mielec & 65 & 56 & 83 & 120 & 81 \\
\hline 26 & Dunajec - Nowy Sącz & 64 & 51 & 90 & 76 & 65 \\
\hline 27 & Dunajec - Żabno & 112 & 96 & 145 & 124 & 117 \\
\hline 28 & San - Radomyśl & 91 & 76 & 121 & 92 & 105 \\
\hline 29 & Wisła - Sandomierz & 110 & 84 & 163 & 132 & 115 \\
\hline 30 & Wisła - Zawichost & 105 & 84 & 148 & 131 & 101 \\
\hline & & & & & & \\
\hline
\end{tabular}




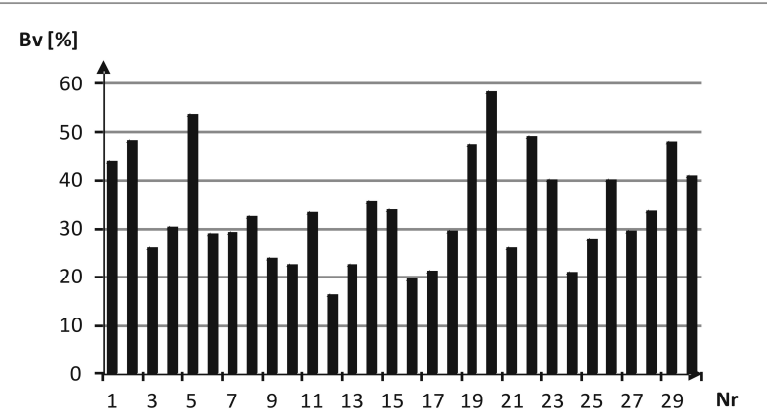

Rys. 2. Odchylenie względne objętości zredukowanej przy zastosowanej liczbie losowej generatora $\mathrm{G}=0,2$ dla wodowskazów z obszaru górnej Wisły usystematyzowanych według wielkości zlewni. $\mathrm{Nr}$ - numer porządkowy zlewni według tabeli 2 . Źródło: obliczenia własne.

Fig. 2. Relative deviation of the reduced volume at the applied random number of the generator $\mathrm{G}=0,2$ for the water-gauges from the region of the Upper Vistula systematised according to the catchment size. $\mathrm{Nr}$ - the catchment ordinal number according to the table 2. Source: own calculations

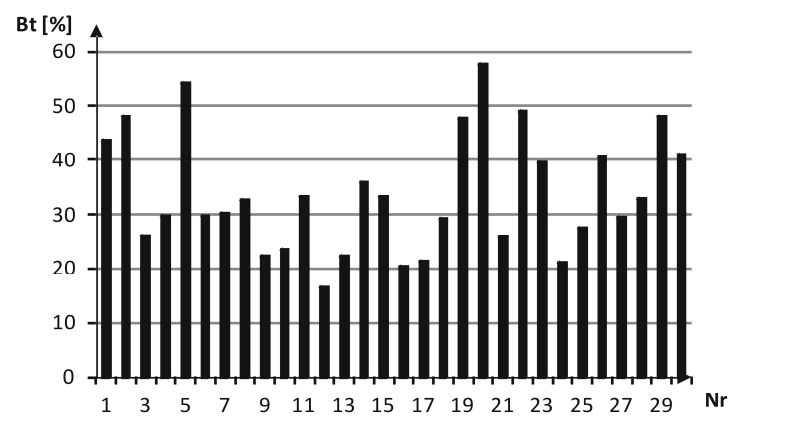

Rys. 3. Odchylenie względne czasu trwania wezbrania hipotetycznego na wysokości poziomu porównawczego $\mathrm{Q}_{\max 50 \%}$ przy zastosowanej liczbie losowej generatora $\mathrm{G}=0,2$ dla wodowskazów usystematyzowanych według wielkości zlewni. $\mathrm{Nr}-\mathrm{nu}-$ mer porządkowy według tabeli 3. Źródło: obliczenia własne.

Fig. 3. Relative deviation of the design flood duration time at the height of the comparative level Qmax50\% at the applied random number of the generator $\mathrm{G}=0,2$ for the water-gauges systematised according to the catchment size. $\mathrm{Nr}$ - the ordinal number according to the table 3. : Source: own calculations 
Przeprowadzone obliczenia wykazały, że odchylenia dla objętości i czasu bazowego kształtują się na bardzo zbliżonym do siebie poziomie. Ich wartości wahają się od $8 \%$ do 29 dla liczby losowej generatora 0,1 dla części wznoszącej i opadającej i od $16 \%$ do $58 \%$ dla liczby losowej 0,2 . Wprowadzona korekta przebiegu w czasie wezbrania poprzez generator liczb losowych ma istotny wpływ na zmianę parametrów wezbrania. Przeprowadzone próby uzależnienia wartości odchylenia względnego od powierzchni zlewni oraz od przepływu maksymalnego nie wykazały współzależności. Na rysunku 4 przedstawiono wzajemne relację pomiędzy odchyleniem względnym dla czasu bazowego $\mathrm{B}_{\mathrm{t}}$ a powierzchnią zlewni.

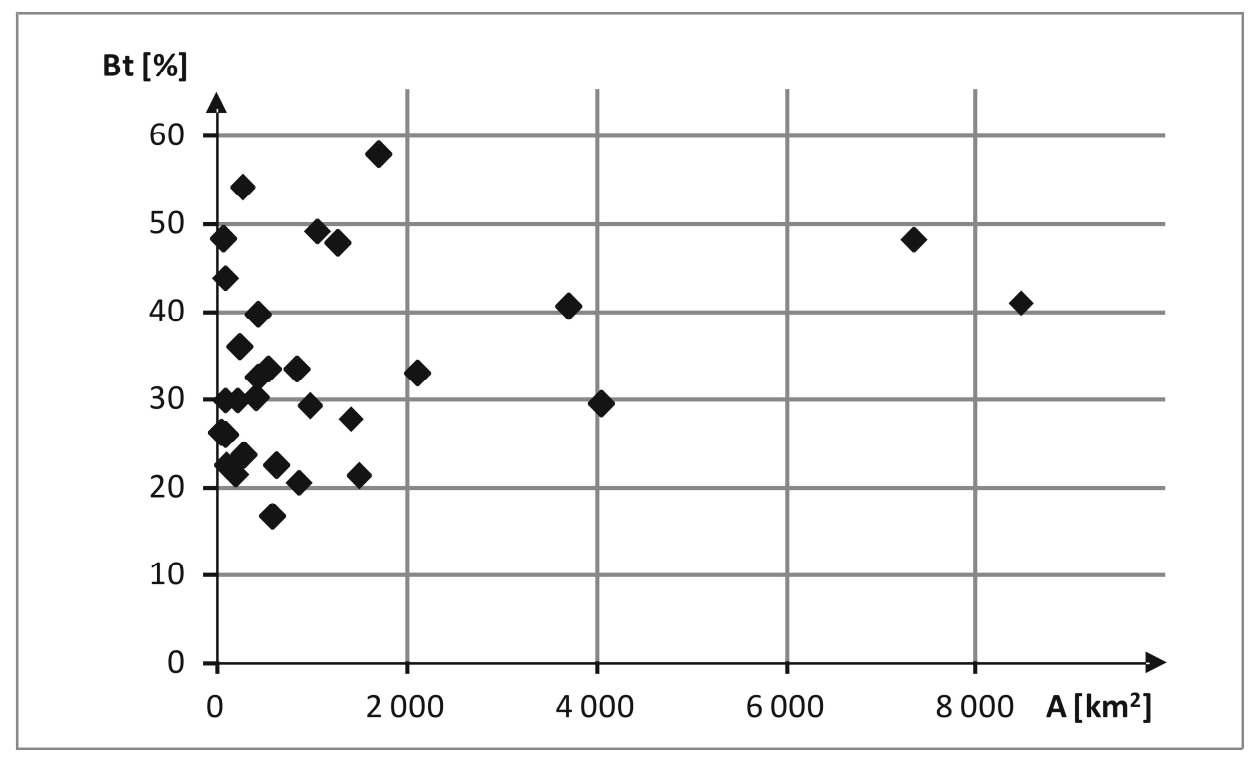

Rys. 4. Zależność odchylenia względnego dla czasu bazowego $B_{t}$ fal hipotetycznych wyznaczonych metodą Hydroprojektu przy liczbie losowej generatora 0,2 dla części wznoszącej i opadającej od powierzchni zlewni dla przekroi wodowskazowych na obszarze górnej Wisły.

Fig. 4. The relation of the relative deviation for the basic time $\mathrm{B}_{\mathrm{t}}$ of the design floods determined with the Hydroprojekt method at the random number of the generator 0,2 for the rising part and declining part for the catchment surface area for the water-gauged cross-sections in the region of the Upper Vistula. Source: own calculations

\section{Podsumowanie i wnioski}

Metoda Hydroprojektu ponad ćwierć wieku temu wprowadziła uzmiennienie parametrów wezbrania hipotetycznego przy zadanej stałej wartości przepływu maksymalnego. Charakteryzuje się ona nadal w warunkach krajowych odmiennym podejściem do problemu wyznaczania fal hipotetycznych. Metoda ta jednak wymaga wprowadzenia pewnych modyfikacji z uwagi na poszerzenie zakresu stosowania fal hipotetycznych. We wcześniejszej publikacji zapropo- 
nowano by wybór wezbrania wzorcowego był dokonywany przez największą zgodność z „formułą na objętość” [11].

Zastosowany w metodzie Hydroprojektu generator liczb losowych w sposób istotny wpływa na końcowe parametry wyznaczanych fal hipotetycznych. Duża rozpiętość odchylenia względnego dla objętości fali hipotetycznej i czasu bazowego wezbrania, wskazują na niekontrolowany sposób wyznaczania przebiegu fal teoretycznych. Może mieć to negatywne konsekwencje przy wyznaczaniu stref zalewu lub przy ocenie ryzyka. Proponuje się aby górne ograniczenie wartości liczby losowej było obniżone z poziomu 0,2 do 0,1. Przy takim ograniczeniu uzyskuje się maksymalne wartości odchylenia względnego poniżej $30 \%$. Niekontrolowany wpływ generatora liczb losowych na parametry wezbrania hipotetycznego mogą być również ograniczone poprzez kontrolę ich zmian w stosunku do wartości parametrów przy wyłączonym generatorze. Takie podejście ma zasadniczą zaletę, wartość górnego i dolnego ograniczenia losowego może być dobierana w zależności od rozwiązywanego problemu i przyjętych a priori dopuszczalnych zmian wartości parametrów. W czasie prowadzonych analiz stwierdzono, że przy stosowanych formułach na wyznaczenie wartości przepływu ma istotny wpływ poziom odcięcia dla części wznoszącej i części opadającej. To zagadnienie wymaga dodatkowych analiz.

\section{Literatura}

[1] Apel H.,Thieken A. H., Merz B., Blöschl G.: A probabilistic modelling system for assessing flood risks. Natural Hazards. Vol. 38 2006, s. 295-308.

[2] Banasik K.: Wyznaczanie wezbrań powodziowych w małych zlewniach zurbanizowanych, Wydawnictwo SGGW 2009, ss. 27.

[3] Ernst J., Dewals B., Detremleur S., Archambeau P.: Micro-scale flood risk analysis based on detailed 2D hydraulic modelling and high resolution geographic data Natural hazards. Natural Hazards. Vol. 55, 2010 s. 181-209.

[4] Gądek W., Książyński K., Nachlik E., Szczepanek R., Ozga-Zielińska M.: Matematyczny model transformacji opadu w odpływ WISTOO. Monografie Komitetu Gospodarki Wodnej PAN. - Z. 182001 ss. 118.

[5] Gądek W.: Matematyczny model odpływu ze zlewni z zastosowaniem zdekomponowanej przestrzennie siatki obliczeniowej. Zeszyty Naukowe Politechniki Krakowskiej 492002 ss. 134.

[6] Gądek W.: Fale hipotetyczne o zadanym prawdopodobieństwie przepływu w kulminacji. Hydrologia w inżynierii i gospodarce wodnej. wodnej T. 1. Warszawa. Komitet Inżynierii Środowiska PAN. Monografia. Nr 68. 2010, s. 177-186.

[7] Gądek W.: Wyznaczanie wezbrań hipotetycznych metodą Politechniki Warszawskiej i metodą Politechniki Krakowskiej w zlewniach kontrolowanych. Cz. I. Opis metod. Czasopismo Techniczne. 2-Ś/2012 z.23. 2012 b, s. 95-104.

[8] Gądek W., Banach Wł., Fiołka I.: Zastosowanie modelu geomorfologicznego do wyznaczania wezbrań hipotetycznych w zlewniach niekontrolowanych. Czasopismo Techniczne z. 1-Ś/2012 z. 4, 2012, s.59-67. 
[9] Gądek W.: Assessment of limnigraph data usefulness for determining the hypothetical flood waves with the Cracow method. Journal of Water and Land Development. No. 21 2014a, s. 71-78.

[10] Gądek W.: Fale hipotetyczne dla zlewni niekontrolowanej. Monografie Komitetu Gospodarki Wodnej PAN z. 20, 2014b, s. 139-149.

[11] Gądek W.: Typowy hydrogram przepływu dla potrzeb wyznaczania wezbrań hipotetycznych. Woda-Środowisko-Obszary Wiejskie. Praca w druku 2015.

[12] Gądek W., Środula A.: Ocena parametrów wezbrań hipotetycznych wyznaczonych metodą Reitza i Krepsa w zlewniach kontrolowanych. Woda-Środowisko-Obszary Wiejskie. t. 14. z. 3 (47) 2014a s. 29-47.

[13] Gądek W., Środula A.: The evaluation of the design flood hydrographs determined with the Hydroproject method in the gauged catchments. Infrastruktura i Ekologia Terenów Wiejskich. 4/3 2014b, s. 1355-1366.

[14] Jonkman S. N., Vrijling J. K., Vrouwenvelder A. C. W.: Methods for the estimation of loss of life due to floods: a literature review and a proposal for a new method. Natural Hazards. Vol. 46, 2008, s. 353-358.

[15] McEnroe B. M. 1992. Sizing stormwater detention reservoirs to reduce peak flow. W: Hydraulic engineering: saving a threatened resource - in search of solutions. Conference Proceeding Paper. Reston. VA. ASCE 1992, s. 719-724.

[16] Ozga-Zielińska M., Gądek W., Książyński K., Nachlik E., Szczepanek R.: Mathematical model of rainfall-runoff transformation - WISTOO. Mathemalical Models of Large Watershed Hydrology, Ed. Singh V. P., Frevert D.K. Water Resources Publications, LLC, Littleton, Colorado 2002, s. 811-860.

[17] Pietrusiewicz I., Cupak A., Wałęga A., Michalec B. 2014. The use of NRCS synthetic unit hydrograph and Wackermann conceptual model in the simulation of a flood wave in an uncontrolled catchment. Journal of Water and Land Development. No. 232014 s. 53-59.

[18] Strupczewski W.: Równanie fali powodziowej. Wiadomości Służby Hydrologicznej i Meteorologicznej. 2(57) 1964, s. 35-58.

[19] Szalińska W., Otop I.: Ocena struktury czasowo-przestrzennej opadów z wykorzystaniem wybranych wskaźników do identyfikacji zdarzeń ekstremalnych. WodaŚrodowisko-Obszary Wiejskie. T. 12. Z. 2 (38) 2012 s. 269-282.

[20] Twaróg B. Optymalna ochrona przed powodziami z uwzględnieniem ryzyka - Gospodarka Wodna nr 42005 s. 137-142.

[21] Twaróg B.: Zastosowanie funkcji Copula do budowy rozkładów prawdopodobieństwa wielowymiarowej zmiennej losowej określanej dla zbioru parametrów fali powodziowej, Czasopismo Techniczne 10-Ś/2006, 2006, s. 177-198.

[22] Twaróg B.: Elementy ryzyka i zarządzania bezpieczeństwem obiektów przeciwpowodziowych - Czasopismo Techniczne z. 3-Ś/2008, 2008 s. 143-159.

[23] Vrijling J. k., Van Hengel W., Houben R. J.: Acceptable risk as a basis for design. Reliability Engineering and System Saferty. Vol. 591998 s. 141-150.

[24] Tokarczyk T. Szalińska W.: The operational drought hazard assessment scheme performance and preliminary results . Archives of Environmental Protection Vol 39 no. 3, 2013 s. 61-77. 
[25] Wałęga A.: Application of HEC-HMS programme for the reconstruction of a flood event in an uncontrolled basin. Journal of Water and Land Development. No 18 2013 s. 13-20.

[26] Wypych A., Ustrnul Z., Henek E.: Meteorological Hazards - Visualization System for National Protection Against Extreme Hazards for Poland. Meteorology Hydrology and Water Management. Vol 2; no 1/2014, s. 37-42.

\title{
ASSESSMENT OF VALUES OF THE RANDOM NUMBER INFLUENCE IN HYDROPROJEKT METHOD ON THE DESIGN WAVE PARAMETERS
}

\begin{abstract}
S u m m a r y
Hydroprojekt method applied for determining determining the design waves uses the values of random number within the range from $-0,1$ to 0,2 from random number generator for showing the time route variation of the flood. The aim of this publication is to verify to what extent the flood parameters such as: volume and duration time, are subject to change as a result of the application of this random number generator. The analysis was conducted for the data registered on 30 water gauges located within the boundaries of the upper Vistula catchment. The selected posts represent the catchments with different surface areas and of different nature. They represent mountainous, mountain-foot, upland and lowland catchments. The smallest catchment Lubieńki has the surface area of $46,9 \mathrm{~km}^{2}$, and the biggest catchment is Vistula catchment up to Zawichost with the area of $50732 \mathrm{~km}^{2}$. While choosing so-called standard design hydrograph for the method, the developed by the author 'formula for volume' was used, and this formula designates satisfactory the value of volume for a set surface area of the catchment. This formula may be used for both Vistula and Odra catchment areas. Due to the fact that in Hydroprojekt method the flood cut-off level is not determined explicitly, for comparative purposes it was assumed that the calculations

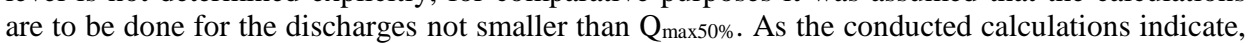
both the volume value and flood duration show great diversity in relation to the flood at the disabled random number generator. The deviation at the number value from the generator 0,2 in the range of rising and declining time in relation to the disabled number generator varies from $16 \%$ to $58 \%$. The similar deviation values were calculated for the values of the flood duration time. The causes for such big range of the results could not be established.
\end{abstract}

Keywords: Hydroprojekt method, design wave, „formula for volume”, Cracow method, flood parameters, standard design flood, random number generator

Przestano do redakcji:30.05.2015 $r$.

Przyjęto do druku:30.10.2015 r.

DOI: $10.7862 / r b .2015 .98$ 